\title{
Zinc Finger CCHC Domain-Containing Protein 8
}

National Cancer Institute

\section{Source}

National Cancer Institute. Zinc Finger CCHC Domain-Containing Protein 8. NCI

Thesaurus. Code C122880.

Zinc finger CCHC domain-containing protein 8 (707 aa, $79 \mathrm{kDa}$ ) is encoded by the human ZCCHC8 gene. This protein plays a role in RNA binding. 